\title{
Green bonds: a survey
}

\author{
Chiyoung Cheong \\ Department of Economics and Finance, City University of Hong Kong, \\ Hong Kong, Hong Kong, and \\ Jaewon Choi \\ Department of Finance, University of Illinois at Urbana-Champaign, Champaign, \\ Illinois, USA and Yonsei University, Seoul, Republic of Korea
}

\begin{abstract}
This paper is a survey of recent academic developments in the literature on green bonds, which have become an important financial instrument in socially responsible investment. This study provides a review of papers that study the market pricing of green bonds, the economic and environmental effects of green bond financing, as well as legal and institutional issues in the green bond market. The literature on market pricing focuses mainly on the existence of greenium, which represents the extent to which green bonds carry a price premium over otherwise identical non-green counterparts. The literature on the economic and environmental effects mainly concerns stock market reaction to green bond issuance and associated economic value implications to other stakeholders, as well as investment in green projects. This paper discusses current issues in the green-bond market and avenues for future research.
\end{abstract}

Keywords Corporate social responsibility (CSR), Green premium, ESG, Sustainable finance, Green bonds, Socially responsible investing (SRI)

Paper type Research paper

\section{Introduction}

Socially responsible investing (SRI) has become one of the most important issues in finance. Reflecting the importance of SRI and environmentally friendly financing in particular, there is also almost an exponential rise in interest in "green finance" and the market for green bonds. As of 2019, the cumulative issuance of green bonds had risen above US\$754bn, comprising 5,931 deals from 927 issuers. The market for green bonds, as measured by the volume in green bonds outstanding, has now risen above US\$250bn and every year the rate of growth hits a new record (See graph in Figure 1). This rapid market growth highlights the importance of the instrument to SRI and makes it important for both policymakers and regulators to understand the extent to which green bond financing impacts market participants, issuers and stakeholders, as well as the broader economy and the natural environment.

In this paper, we survey recent developments in green bonds as discussed in the finance literature. Green bonds are a recent innovation in the sustainable industry, where the proceeds of the bonds are earmarked for environmentally friendly projects. Multiple disciplines in the academic literature discuss green bonds. Apart from the financial

(c) Chiyoung Cheong and Jaewon Choi. Published in Journal of Derivatives and Quantitative Studies: 선물연구. Published by Emerald Publishing Limited. This article is published under the Creative Commons Attribution (CC BY 4.0) licence. Anyone may reproduce, distribute, translate and create derivative works of this article (for both commercial and non-commercial purposes), subject to full attribution to the original publication and authors. The full terms of this licence maybe seen at http:// creativecommons.org/licences/by/4.0/legalcode

JEL classification - G12, G18

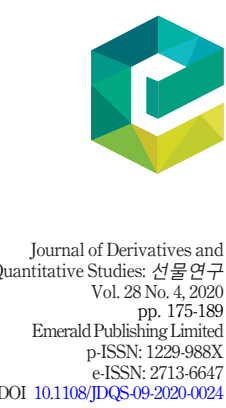


JDQS

28,4

176

Figure 1.

Green bond market size

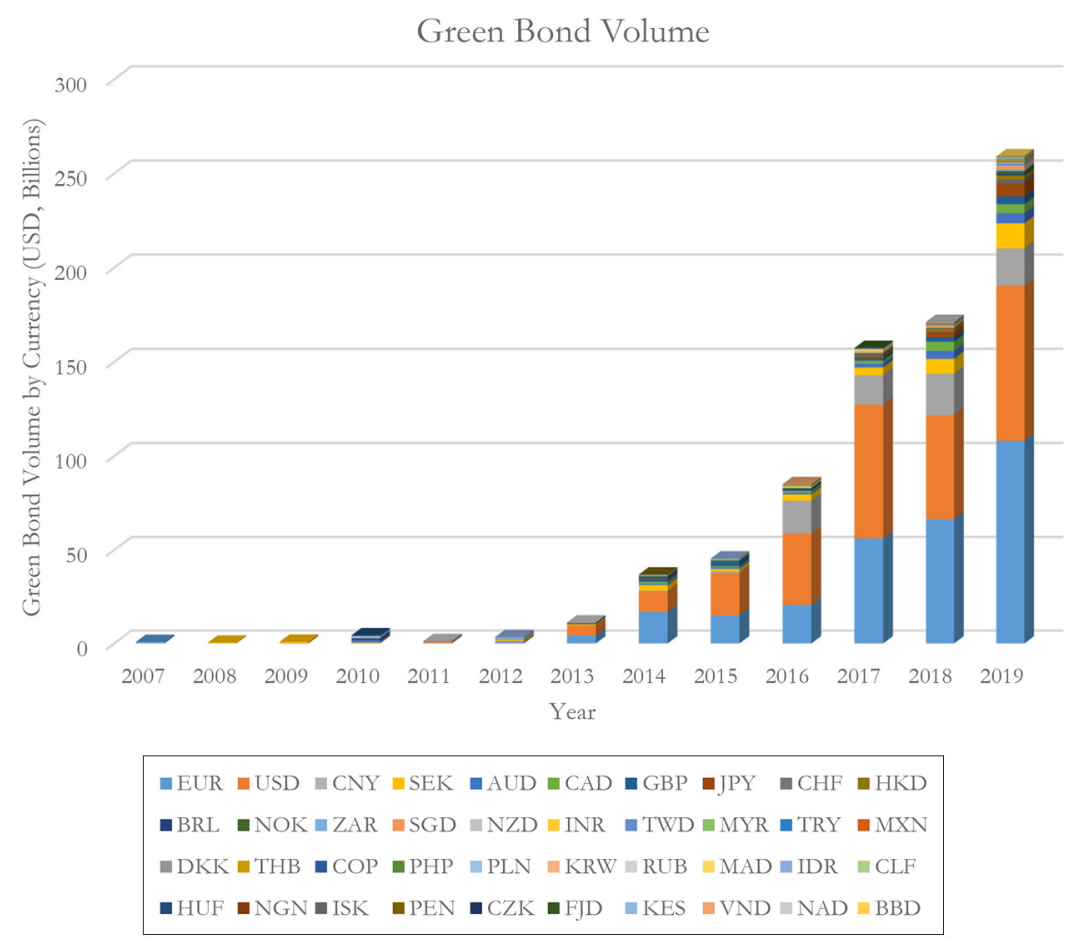

Notes: This graph shows the evolution of green bond market volume by issuing currency. Total volume is indicated in billions of USD

Source: Climate Bonds Initiative

economics literature, green bonds have become an important topic in many other disciplines in business and economics including marketing or management strategies, as well as in the legal, ecological and even sustainable energy literatures that focus on the impact of green financing. A simple search in Google Scholar returns more than three thousand academic papers that have been written in the past five years, showcasing growing interest in studying multiple issues related to green bonds. We focus nonetheless on the finance implications of green bonds, as we regard green bonds as a recent innovation in sustainable finance with the potential to have large economic and financial consequences for investors, issuers and other stakeholders associated with issuers.

There are two main focuses in the finance literature that examines the economic implications of green bond financing. The first concerns mainly the market pricing of green bonds in both the primary and secondary markets and examines the impact of green bonds on market participants. In particular, studies in the literature examine the "greenium" or the price premium that investors are willing to pay for green bonds that they would not pay for their non-green counterparts. According to the investor taste theory, investors are willing to pay more for green bonds and thus the greenium should be positive. This theory argues that investors are willing to trade off wealth for societal benefits, and this translates to a positive premium for green securities. The key economic assumption in this theory is that markets 
for green investors and non-green investors are segmented. There is also a story according to which green bonds should carry a negative premium because green investing does not generate positive net present value (NPV). It is also possible that the greenium is zero, that is, the pricing of green bonds is equivalent to that of non-green bonds, which, when properly considered, means there should be no premium for green bonds.

The key econometric issue in searching for the greenium is selection bias in constructing a sample of green bonds. In an ideal situation, an econometrician would prefer a random assignment of green labeling, but that is never the case in reality. In practice, empirical studies of green bond pricing therefore typically rely on some matching process, either exploiting bonds issued by the same firms as in the approach of Choi et al. (2019) or using propensity-score matching based on observable characteristics. We find that existing studies report mixed results for green bond pricing depending on the sample selection and matching methods.

The other area of focus in the finance literature concerns the value implications for green bond issuers. On the one hand, financing through green bonds is an expensive source of capital compared with financing through brown bonds. That is, firms should paymore to issue green bonds because of either the direct costs involved in the certification process for green labeling or the indirect costs arising from limited usage of green bond proceeds. These considerations could discourage firms from issuing green bonds. On the other hand, issuing green bonds could send a costly signal that informs the market that a firm has long-term sustainable investing at heart, and the market could take that as a positive sign. In particular, going green can increase firm value because investing in green projects can be profitable in the long run as these projects bring higher positive NPV. For example, green projects themselves turn out to be highly profitable in the long run and they are fundamentally safer projects with limited disaster-like risk and the higher NPV of such projects that will accrue to equity holders. That said, the positive effects of green financing can also incentivize firms to practice greenwashing - conveying a misleading picture of a firm's commitment to green business practices and products. In other words, going green could be just a show or marketing gimmick.

Finally, we discuss the current results in the literature that examine the extent to which green bond financing makes an actual difference in the environmental effects of the associated investments. There are both short-run and long-run effects. In the short run, the positive impact of green bonds is seen in increased funding of environmentally friendly projects that are otherwise difficult to finance. A long-run effect will concern a more fundamental issue as to whether projects financed through green bonds indeed reduce environmental risks. We also survey studies of legal issues associated with green bond financing, which examine the legal framework that governs this instrument, both within and across countries. Because green bonds are self-labeled, and also because of the positive market reaction at issuance, there is a strong incentive on the part of issuers to label their new bond issues as green bonds without changing them in substance. Investigating these issues is particularly interesting, given the rapid growth of the market in recent years.

The rest of the paper is structured as follows. In Section 2, we summarize the background against which green bonds operate and discuss recent developments in the market. In Section 3, we survey recent studies that examine market pricing of green bonds and in particular the existence of a greenium. In Section 4, we discuss recent papers that study how green bond issuance impacts stakeholder value and explore its effects on the stock market responses to green bond issuers. Section 5 surveys papers that examine the environmental effects of green bond financing and legal issues surrounding green labeling. We conclude in Section 6. 
JDQS

28,4

\section{Green bonds: background conditions}

Over the past several decades, green bonds have become an iconic financial instrument for green investing and financing. Green bonds abide by the Green Bond Principles (GBP) set forth by the International Capital Market Association (ICMA) that are designed to enable issuers to raise capital for projects that bring environmental benefits. Green bonds address "key areas of environmental concern such as climate change, natural resources depletion, loss of biodiversity and air, water or soil pollution [1]." They can be project bonds or assetbacked securities backed by a project. Green bond issuers range from international organizations to national or local governments to corporations, and the market for green bonds is growing in scope and size. Green bonds are the first debt instrument to contribute to corporate governance, which traditionally has focused on impacts on shareholders.

Green bonds were first launched in 2007, by the World Bank Green Bonds program and, in 2008, by the European Investment Bank (EIB) as Climate Awareness Bonds. This instrument was set up so that green bonds would be similar to conventional bonds in terms of the risk-reward equation and structure. Less than a year after this introduction, in November 2008 the World Bank issued its first green bond. The EIB also launched its first green bond as a source of financing for its climate projects and the Luxembourg Stock Exchange was chosen as its primary listing exchange, which, to date, remains the top green bond listing venue.

The green bond market has grown significantly since its debut. In 2014, the GBP were first developed by a consortium of investment banks. This was a crucial step because establishing a standard procedure for issuing green bonds guaranteed adequate transparency and credibility for this instrument. The ICMA served as GBP secretariat to provide administrative guidance for green bond issuance.

A decade after being introduced, with figures growing exponentially year after year, green bond and loan issuance was reported to have reached USD\$257.7bn in 2019. This represents $51 \%$ growth over the 2018 figure. Market volume in green bonds is being driven primarily by the European market, which accounts for almost half of global issuance. The runner-up is the Asia-Pacific market, with the North American market a close third.

The growth of the green bond market has been accompanied by a noteworthy innovation in the instrument. De Spiegeleer and Schoutens (2019) document a variant of "vanilla" green bonds, namely Reverse Green Bonds. With reverse green bonds, coupon payments are linked to a company's environmental, social and governance (ESG) performance. They work much like contingent convertible bonds in that they ask investors to participate in an ESG profile. In the event of an ESG trigger, the investor loses coupons and the company will instead pay the coupons into an ESG fund.

\section{Pricing green bonds}

A classic puzzle in the "doing well by doing good" literature is whether there is any premium associated with "ethical" instruments such as green bonds. In this section, we provide a brief overview of the central issues in green bond pricing and summarize recent empirical evidence reported in the literature.

How should green bonds be priced compared with otherwise similar non-green bonds? The debate regarding the greenium has attracted great interest. In canonical asset-pricing models, the intrinsic value of any financial instrument should equal the discounted value of future cash flows. As green bonds are fixed-income instruments, their cash-flow streams are known in advance with some risk involved with potential defaults of issuers, while the discount rates depend on interest rate risk, the creditworthiness of green issuers and the clienteles of investors in the market. 
We categorize the current results reported in the literature as follows. The first group consists of studies that argue for a positive greenium and hold that investors are willing to pay a price premium for an asset that brings societal benefits. As such, green bonds carry lower yields or lower expected returns than their non-green counterparts. The second group reports opposite results, finding that the new-ness of the instrument and the relative risk (or lack thereof) associated with, for example, a limited investor base, enables green bonds to carry higher yields or bring higher expected returns. Another group of studies finds that green bonds are in essence not substantially different from vanilla brown bonds - which, when matched perfectly, should not exhibit any difference in pricing - implying that no greenium exists. We discuss current developments in the literature in the remainder of this section.

\subsection{Studies that document a positive greenium}

Quite a few empirical and theoretical studies document that investors willingly trade wealth for societal benefits and are therefore willing to pay a premium (i.e. accept lower yields) for climate-friendly bonds. Baker et al. (2018) develop an asset-pricing model, incorporating investors' tastes into a theoretical framework in which firm behavior is determined largely exogenously irrespective of investor sentiment. Based on the prediction that this framework generates, Baker et al. (2018) find, using US green and non-green bonds, that securities with higher environmental scores generate lower expected returns, which they interpret as evidence of the existence of a positive greenium.

Several other studies report results that are aligned with this prediction, arguing that there is a premium for being green. Zerbib (2019), for example, examines a sample of 135 USA-issued green bonds and their non-green counterparts matched based on the same issuer and same bond-level characteristics. Using this matched comparison sample, the paper finds that the average greenium, the difference between green bond yields and their matched counterparts, is 2 bps. The paper further estimates that the greenium can be as high as 8 bps when accounting for the difference in liquidity as well, considering that green bonds tend to be less liquid. These results are based on a relatively small number of sample bonds, perhaps because the matching procedure based on issuers and bond characteristics reduces the sample size. Ehlers and Packer (2017) also find similar results for the existence of a greenium, using a sample of 21 green bonds issued between 2014 and 2017 and comparing at-issuance yields of green and non-green counterparts of the same issuers. They compare at-issuance credit spreads of 21 green bonds to the credit spreads of same issuers at the closest possible issue dates. They find, however, that following issuance these bonds tend to perform similarly in the secondary market. Hachenberg and Schiereck (2018) find that green bonds trade more tightly than their brown bond counterparts as well.

Kapraun and Scheins (2019) also examine the extent to which green bonds are traded at a premium in comparison with non-green bonds. They use a wider data sample of more than 1,500 green bonds that are issued internationally and examine both the primary (at issuance) and secondary (traded) market pricing. They find that a subset of green bonds that are issued by supranationals, governments or very large companies indeed trade at a premium at issuance. Nonetheless, they also document that on the secondary market the premium then continues only for government bonds and that, overall, there is instead a discount of 14 bps. Fatica et al. (2020) examine a sample of 1,397 green bonds, of which 637 had been certified by a third party. They focus mainly on examining whether green bonds issued by financial institutions bring a higher greenium than green bonds issued in other sectors. They find that, although there is a premium for green bonds issued by supranational 
JDQS 28,4

institutions, corporate green bonds issued by financial institutions do not have such an effect.

The vast majority of US green bond issuers are municipalities. Partridge and Medda (2018) examine the greenium among US municipal bonds in primary and secondary markets. They compare same-issuer green and non-green bonds and analyze the yield curves of municipal bonds, the latter of which enables them to compare green and non-green bonds in a broader sense. They conclude that the pairwise analysis of green bonds and their identical counterparts reveals a growing trend toward a greenium in the US municipal bond market.

Gianfrate and Peri (2019) use propensity-matching to address the inherent selection issue in the comparison of green and non-green bonds and examine whether there is a green bond premium in the euro-denominated market. They identify 121 fixed-rate green bonds and examine the differences between their actual spreads at issuance and their counterfactual spreads that would have been obtained for conventional bonds. They document a greenium of approximately $17 \mathrm{bps}$, which suggests that green bonds are a convenient instrument for issuers, even taking into consideration the 0.1 bps cost of earning a green label or rating.

\subsection{Negative results for a greenium}

In contrast to the studies discussed above that document positive evidence for greenia, a several argue for the opposite result. Green bonds are a relatively newer class of instruments and could be construed as either riskier or less approachable by investors. As such, investor demand for green bonds can be weaker, leading to higher yields attached to the green label. Karpf and Mandel (2017) examine the yields of US municipal bonds that are labeled "green." They find that, among the 1,880 bonds that they study using Oaxaca-Blinder decomposition, green bonds trade in the secondary market at an average $7 \mathrm{bps}$ - higher yield than that of their counterpart "brown" bonds with similar characteristics. This result can be interpreted as demonstrating that either investors actually find green-ness less attractive or they perceive added risk in green bonds and require higher yields than their counterparts to become tradable. Bachelet et al. (2019) also find that green bonds bring higher yields than their closest brown counterparts. Using a relatively small sample of 89 green bond pairs, they find that this deviation reflects issuer characteristics or green verification.

Another group of studies argues that, because green bonds trade pari passu to vanilla bond issuances, there should be no difference in yields as well, implying that there is no greenium, either positive or negative. In a competitive capital market with no friction, for example, any price differential between green and non-green bonds tends to disappear to the extent that there are marginal investors with large amounts of capital who would exploit any price differentials between green and non-green bonds. Larcker and Watts (2019) take up the question whether investors value ESG investments above and beyond the fundamental risks of and returns on such securities. As such, they take a green bond and try to match it to the most identical counterpart, using a sample of 640 matched pairs of green and non-green US municipal bonds issued by the same issuer on the same day, with identical maturity and rating. They find that when they are matched to the last dot, holding risk and return constant and are presented ex ante to investors, the greenium is essentially zero. While they conduct their study carefully, Larcker and Watts (2019) examine only one subset of green bonds - namely, US local government-issued bonds - potentially limiting its generalizability. Reed et al. (2017) also find no price premium for green bonds. They attribute this to a lack of investor trust in the environmental impact of green bonds that reflects the difficulty involved in confirming that green bonds are truly green. 
Selection bias inherently plagues the study of green bond pricing. In an ideal situation, a well-designed study would assign green labeling randomly to bonds that are otherwise identical. However, such random assignment is not possible and thus many previous studies that we discuss employ matching exercises that compare same-issuer bonds or bonds that have similar observable characteristics. These differences in empirical methods are perhaps the main reason that studies provide mixed results across sample periods and markets.

One selection issue that concerns mainly fixed-income instruments is market liquidity. The vast majority of green bonds are either corporate or municipal bonds, which tend to trade infrequently. The resulting illiquidity premium is also known to account for the majority of yield premia for such illiquid fixed-income securities. It is also possible that pricing differentials for green bonds arise from the inherent liquidity differentials. That is, any pricing difference reflects the liquidity of green bonds or lack thereof. To examine this possibility, Wulandari et al. (2018) study the impact of liquidity risk on green bond yield spreads. They use 64 green bonds that are matched to 56 vanilla bonds and the Lesmond, Ogden and Trzcinka liquidity measure proposed by Chen et al. (2007) and the bid-ask spread to study the impact of liquidity on green bond pricing. They find that liquidity risk is not a significant driver of green bond yield spreads.

Investors are also concerned that green bonds could be prone to greenwashing. Green bonds are self-labeled, and there is no specific enforceable definition or institution that can guarantee the quality of so-called green bonds. To examine this issue of greenwashing, Deng et al. (2019) examine whether the market prices not just green labeling but also green investing itself. They exploit a unique feature of Chinese green bonds in which the proceeds can be used in part for non-green projects. They find that any positive premium that a green bond generates in the overall sample disappears for the subsample of browned-out green bonds, and any significant pricing difference is driven by green bonds all the proceeds from which are used for green projects. These results suggest that investors are able to identify greenwashing and that any reward that greenness brings is paid only for completely green bonds. Relatedly, Katori (2018) focuses specifically on the effects of third-party certification, which is another mechanism that ensures that green-labeled bonds are used to finance environmentally friendly projects. Green bonds that have either complied with climate bonds initiative (CBI) standards or received Green Bond Ratings from a rating agency have longer maturity but carry a lower premium than their brown counterparts. This research is subject to the limitation involved in matching the sample bonds with bonds in a control group.

\section{Green bonds and firm value}

Another interesting area that is explored in the green bond literature is the extent to which issuing firms, or green issuers, benefit from employing such financial instruments. We first discuss the economic mechanisms through which green bond issuance can affect the equity value of issuing firms. Understanding the link between financing through SRI bonds and the resulting effects on firm value might explain why some firms prefer issuing green bonds in lieu of conventional debt.

Ceteris paribus, green bonds are pari passu to their brown counterparts except for their constraint in the use of the proceeds. This fact implies that, except for their greenness, there is no a priori reason that green bond issuance should affect firm value in a way that differs from the effects of issuing regular bonds. The added constraint imposed by green bond issuance that restricts proceeds from bond financing can limit firms' optimal investment choices and operating decisions. Moreover, issuing green bonds rather than conventional 
JDQS 28,4

182

bonds is costly because issuers typically need to submit to third-party validation that the proceeds will be spent on environmentally friendly projects to have the bonds certified as green.

On the other hand, green bond issuance can increase equity and overall value for issuers' stakeholders. First, going green works as a signaling device for issuers. A costly commitment to green-ness signals managerial engagement in long-term sustainability, which in turn signals concern for long-term shareholder value. This may cause investors to read a signal about a firm that issues green bonds positively. Second, going green can increase firm value because investing in green projects can be profitable in the long run as these projects generate higher positive NPV. This can occur in both the cash-flow and discount-rate channels. Green projects themselves turn out to be highly profitable in the long run and they are fundamentally safer projects with limited disaster-like risk, the latter factor also increasing the NPV of such projects. Finally, going green can reduce the cost of debt capital to the extent that green bonds carry a greenium, which should help increase firm value. In the remaining section, we discuss the existing results reported in the literature.

\subsection{Empirical evidence}

Flammer (2020) examines the economic and environmental effects of green bonds on issuing corporations, using firm-level data on 384 public-company green bonds spanning from 2013 through 2017 and analyzes stock market reactions to issuance announcements. She finds positive announcement returns on green bond issuances and shows that these return effects are stronger for third-party-certified bonds and first-time issuers. These stocks are also held by longer-term investors and green investors. Flammer (2020) also finds that green issuers leave significant environmental footprints, as shown by their environmental ratings and $\mathrm{CO}_{2}$ emissions, arguing that green bonds constitute a successful commitment mechanism for issuing corporations and that investors value such a practice. Tang and Zhang (2018) examine an international green bond dataset based on 28 countries and ask whether green bond issuance benefits issuers' shareholders. Like Flammer (2020), they also find a positive stock market reaction to green bond issuance. This stock market reaction is not, however, associated with a significant price premium for green bonds but is instead related to a more extensive institutional firm ownership after green bond issuance. The liquidity of an issuing firm's stock also improves the following issuance.

Wang et al. (2020) focus specifically on Chinese green bonds to examine stock market reactions following issuance. While they also find positive announcement returns on green bond issuances, unlike Tang and Zhang (2020) they find that this positive stock reaction comes with a pricing premium on corporate green bonds that prices them higher than conventional bonds. They also find that this effect is stronger for corporate issuers with less concentrated ownership and those that are held by longer-term institutional investors. Several other papers, such as Kuchin et al. (2019) and Glavas (2018), also study the impact of green bond issuance on issuing firms using the USA or international data. The results reported in these studies together suggest that the stock market for the most part reacts positively to green bond issuance.

Unlike the abovementioned studies that document positive value for equity holders, some studies provide evidence that the market does not always welcome green bond issuance. Lebelle et al. (2020) examine a dataset on international corporate green bonds to analyze issuers' financial performance as measured by their cumulative stock returns. Their main results show that cumulative stock returns around green bond issuance range between $-0.5 \%$ and $-0.2 \%$, depending on which asset-pricing model is used to calculate abnormal stock returns. This result indicates that green bond issuance can be costly. That is, green 
bond issuance could signal that going green will incur sizeable operational and capital expenditures that investors could interpret as increasing uncertainty regarding future profitability. Lebelle et al. (2020) also document that negative stock market reactions are stronger in developed markets, suggesting that investors in such mature markets view green bond issuance more negatively than investors in emerging markets.

\section{The real side of green bond financing}

In the previous sections, we summarized studies that examine the impact of green bond financing on market participants and firms' stakeholders. A natural question arises: What are the real effects of green bond issuance? In the short run, the potential positive impact of green bond financing would be the promotion of environmentally friendly projects that are otherwise difficult to finance. In the long run, the question centers on the issue of whether such projects indeed reduce environmental risks. If they have no real effects in the environment, green bonds might be nothing but a marketing gimmick, a new security with a fancier name, prone to greenwashing. It important question to empirically examine the extent to which green finance has real effects beyond finance.

We then discuss a related but distinct issue involving green bond financing that is also critical. Because green bonds are self-labeled and also because of positive market reactions at issuance, there is a strong incentive on the part of issuers to label their new bond issues green without making actual changes. Investigating this issue is particularly interesting given the rapid growth of the market in recent years.

\subsection{Studies of green bonds and their real effects}

Glomsrød and Wei (2018) use a general equilibrium model to simulate how green finance might affect not only the economy but also climate change. They find that green investing increases GDP and that it shifts income from capital owners to wage earners. It also reduces

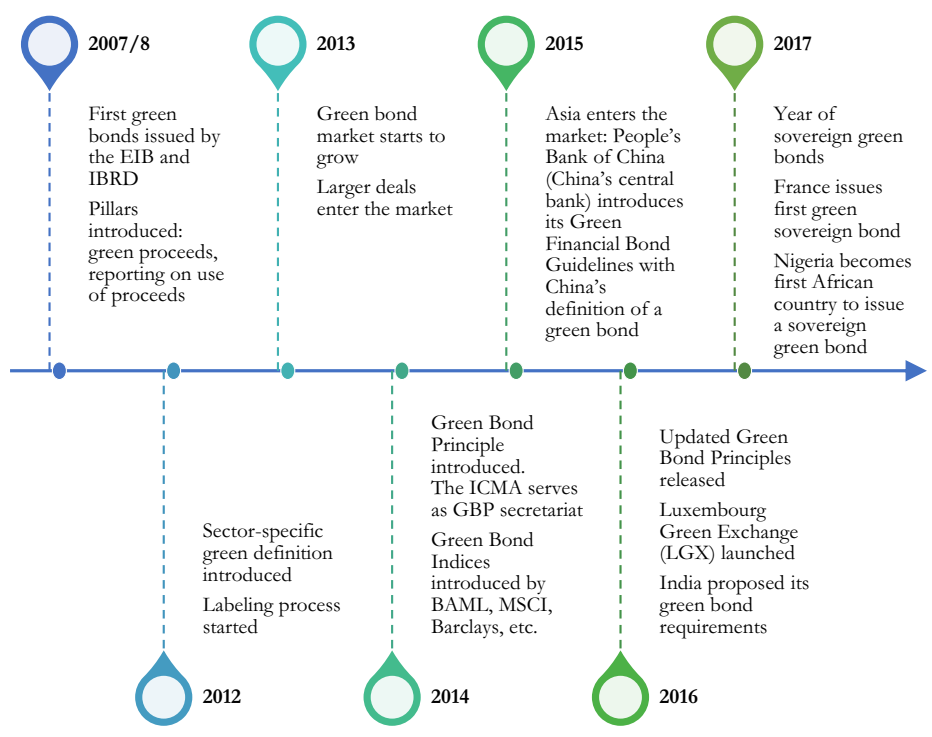

Note: Above is a brief history of landmark events concerning green bonds

Figure 2. Green bonds history 


\section{JDQS 28,4}

\section{4}

\begin{tabular}{l} 
Study \\
\hline Baker et al. (2018) \\
Zerbib (2019) \\
Kapraun and Scheins (2019) \\
Partridge and Medda (2018) \\
Fatica et al. (2020) \\
Ehlers and Packer (2017) \\
Hachenberg and Schiereck (2018) \\
Gianfrate and Peri (2019) \\
Karpf and Mandel (2017) \\
Bachelet et al. (2019) \\
Larcker and Watts (2019) \\
Reed et al. (2017) \\
Wulandari et al. (2018) \\
Deng et al. (2019) \\
Katori (2018)
\end{tabular}

$\begin{array}{ll}\text { Nature } & \text { Greenium } \\ \begin{array}{l}\text { Theoretical, } \\ \text { empirical }\end{array} & \text { Positive } \\ \text { Empirical } & \text { Positive } \\ \text { Empirical } & \text { Positive for a subset } \\ \text { Empirical } & \text { Positive, growing trend } \\ \text { Empirical } & \text { Positive for a subset } \\ \text { Empirical } & \text { Positive on primary market, zero on secondary } \\ & \text { market } \\ \text { Empirical } & \text { Positive } \\ \text { Empirical } & \text { Positive } \\ \text { Empirical } & \text { Negative } \\ \text { Empirical } & \text { Negative } \\ \text { Empirical } & \text { Zero } \\ \text { Empirical } & \text { Zero } \\ \text { Empirical } & \text { Liquidity not a significant driver of greenium } \\ \text { Empirical } & \text { Investors can identify greenwashing } \\ \text { Empirical } & \text { Rated green bonds have longer maturity and bring } \\ & \text { a lower premium }\end{array}$

Note: This table summarizes the main findings pertaining to the green premium in the recent literature

global coal consumption, increases the market share of non-fossil electricity and reduces global $\mathrm{CO}_{2}$ emissions. Flammer (2020) focuses instead on firm-level data on public firms that have issued green bonds. She finds a significant increase in environmental performance, suggesting that the commitment to climate-friendly investments has not been made in vain. She also finds that this effect is significant only for firms that have certified their green bonds through independent third parties.

Some consider the emergence of green bonds and the growth of climate finance as a key tool for encouraging ethical responsibility on the part of financial intermediaries in the face of climate change. Wörsdörfer (2019) argues that financial institutions play a crucial role in determining whether financial resources are distributed in an ethical and environmentally friendly manner and these institutions can ensure that the economy is transitioning to a green orientation. To this end, Revelli and Paranque (2017) propose an ethico-economic framework in which they examine whether green bonds can perform as a tool that facilitates the transition to a sustainable economy.

\subsection{Legal issues surrounding green labeling}

We now discuss the legal environment associated with the labeling of green bonds. This is a tricky area because most jurisdictions do not impose direct public regulations regarding the issuance and certification of green bonds. No single, uniform, standardized definition of green bonds in this market has been established, and as such the regulation of or enforcement of rules pertaining to green bonds merits investigation. This lack of uniform regulation and standardization is in a sense allowed by design so that self-labeling is sufficient for a green bond to be categorized as green and to a certain degree lets the market play the disciplining role that discerns true green issuers from greenwashers, which perhaps helps explain why the market has grown substantially. Nonetheless, several papers analyze how the green bond legal framework is constructed and operated, both within and across countries. 
Inderst et al. (2012) summarize several definitions of green investment. Because definitions of green investment abound, Inderst et al. (2012) refrain from selecting one correct definition but rather analyze the commonalities and inconsistencies they find. They argue that green bonds provide a diversification benefit to holders because they are not highly correlated with other bonds.

Rose (2018) examines the certification process for green bonds. The CBI adopts the GBP established by the ICMA and aims to create a liquid-climate bond market. The CBI plays a key role in certifying climate bonds. To have an issuance certified as a climate bond, the issuer must complete a climate bonds information form and submit the form to the Climate Bonds Standard Secretariat prior to issuance. If the issuer wishes to obtain pre-issuance certification for a bond, the issuer must also engage a verifier to either provide an "assurance report" confirming that the issuance complies with climate bond standards or undertake an "agreed-upon procedures engagement" to assess compliance with climate bonds standards. Similarly, issuers may appoint a verifier to conduct a post-issuance "assurance engagement." Rose (2018) also documents several case studies to demonstrate the quality of the assurance that the $\mathrm{CBI}$ provides.

Park (2018) and Park (2019) suggest that, given current regulation environments, or given the lack of effective regulations, the de facto regulators of green bonds are market investors. He proposes a private governance regime that would operate on top of public regulation, whose certification would be inherently investor-oriented. Because there is no government body that can verify the green-ness of green bonds, investors themselves must act as regulators, for example, by valuing the certification of green bonds in bond prices. Such a hybrid governance mechanism would enable the private governance mechanism to address the limitations of public regulations.

Deschryver and de Mariz (2020) combine an extensive literature review with market data analysis and interviews of green bond market participants. They identify the largest market impediments as:

- a lack of global standards;

- greenwashing risks; and

- issuance costs.

\section{Conclusion}

In this survey, we summarize current developments in the green bond literature and discuss important questions. The green bond market has grown rapidly, and we have seen quite a few studies that address the central questions about the market. We discuss three main research areas. First, we survey prior studies that examine green bond pricing in both the primary and secondary markets. Although we find that more studies report positive evidence for the greenium, the results vary depending on sample selection and empirical methodology. The central issue is the inherent selection bias associated with green labeling of bond issues. Second, we discuss studies that examine the impacts of green bond issuance on firm value. The general consensus in the literature is that the market tends to favor green bond issuance, as evidenced by positive stock market reactions. Limited data availability has led the literature to focus on the value implications for equity holders, but it would also be an interesting open empirical question to examine the implications for other stakeholders. Finally, we survey the real effects and legal issues surrounding green bond issuance. These issues lie at the heart of green financing or, more generally, overall SRI, and it remains to be seen what long-term benefits green bond financing and investing will bring to the economy and the environment. These are promising areas that call for further research. 


\section{Note}

1. www.icmagroup.org/green-social-and-sustainability-bonds/green-bond-principles-gbp/

\section{References}

Bachelet, M.J., Becchetti, L. and Manfredonia, S. (2019), "The green bonds premium puzzle: the role of issuer characteristics and third-party verification", Sustainability, Vol. 11, p. 1098.

Baker, M.P., Bergstresser, D.B., Serafeim, G. and Wurgler, J.A. (2018), "Financing the response to climate change: the pricing and ownership of U.S. green bonds", Working Paper.

Chen, L., Lesmond, D.A. and Wei, J. (2007), "Corporate yield spreads and bond liquidity”, The Journal of Finance, Vol. 62 No. 1, pp. 119-149.

Choi, J., Hoseinzade, S., Shin, S. and Tehranian, H. (2019), "Corporate bond mutual funds and asset fire sales", Journal of Financial Economics, Forthcoming.

De Spiegeleer, J. and Schoutens, W. (2019), "Sustainable capital instruments and their role in prudential policy: reverse green bonds", Working Paper.

Deng, Z., Tang, D.Y. and Zhang, Y. (2019), "Is 'greenness' priced in the market? Evidence from green bond issuance in China”, Working Paper.

Deschryver, P. and de Mariz, F. (2020), "What future for the green bond market? How can policymakers, companies, and investors unlock the potential of the green bond market?", Journal of Risk and Financial Management, Vol. 13 No. 3, p. 61.

Ehlers, T. and Packer, F. (2017), "Green bond finance and certification”, BIS Quarterly Review September 2017.

Fatica, S., Panzica, R. and Rancan, M. (2020), "The pricing of green bonds: are financial institutions special?”, Working Paper.

Flammer, C. (2020), “Corporate green bonds”, Journal of Financial Economics (JFE), Forthcoming.

Gianfrate, G. and Peri, M. (2019), "The green advantage: exploring the convenience of issuing green bonds", Journal of Cleaner Production, Vol. 219 Forthcoming.

Glavas, D. (2018), “How do stock prices react to green bond issuance announcements?”, Working Paper.

Glomsrød, S. and Wei, T. (2018), "Business as UNusual: the implications of fossil divestment and green bonds for financial flows, economic growth and energy market (February 16, 2016)", Energy for Sustainable Development, Vol. 44, pp. 1-10, doi: 10.1016/j.esd.2018.02.005.

Hachenberg, B. and Schiereck, D. (2018), "Are green bonds priced differently from conventional bonds?”, Journal of Asset Management, Vol. 19 No. 6, pp. 371-383.

Inderst, G., Kaminker, C. and Stewart, F. (2012), "Defining and measuring green investments: implications for institutional investors asset allocations", OECD Working Papers on Finance, Insurance and Private Pensions, No. 24, OECD Publishing.

Kapraun, J. and Scheins, C. (2019), “(in)-credibly green: which bonds trade at a green bond premium?”, Working Paper.

Karpf, A. and Mandel, A. (2017), “Does it pay to be green?”, Working Paper.

Kuchin, I., Baranovsky, G., Dranev, Y. and Chulok, A. (2019), "Does green bonds placement create value for firms?", Higher School of Economics Research Paper No. WP BRP 101/STI/2019.

Larcker, D.F. and Watts, E. (2019), "Where's the greenium?", Rock Center for Corporate Governance at Stanford University Working Paper No. 239, Stanford University Graduate School of Business Research Paper No. 19-14, Journal of Accounting and Economics, Volume 69, Nos 2/3, p. 101312.

Lebelle, M., Lajili Jarjir, S. and Sassi, S. (2020), "Corporate green bond issuances: an international evidence”, Journal of Risk and Financial Management, Vol. 13 No. 2, pp. 1-21. 
Park, S. (2018), "Investors as regulators: green bonds and the governance challenges of the sustainable finance revolution ", Stanford Journal of International Law, Vol. 54 No. 1, p. 2018.

Park, S. (2019), "Green bonds and beyond: debt financing as a sustainability driver", in Sjåfjell, B. and Bruner, C.M. (Eds), Cambridge Handbook of Corporate Law, Corporate Governance and Sustainability, (Cambridge University Press), Chapter 42.

Partridge, C. and Medda, F. (2018), "Green premium in the primary and secondary US municipal bond markets”, Working Paper.

Reed, P., Cort, T. and Yonavjak, L. (2017), "Data-driven green bond ratings: a market catalyst", Journal of Investing, Vol. 28 No. 2, p. 2019.

Revelli, C. and Paranque, B. (2017), "Ethico-economic analysis of impact finance: the case of green bonds", Working Paper.

Rose, P. (2018), "Certifying the 'climate' in climate bonds", Ohio State Public Law Working Paper No. 458.

Tang, D.Y. and Zhang, Y. (2018), "Do shareholders benefit from green bonds?”, Journal of Corporate Finance, Vol. 61, p. 101427.

Wang, J., Chen, X., Li, X., Yu, J. and Zhong, R. (2020), “The market reaction to green bond issuance: evidence from China ", Pacific-Basin Finance Journal, Vol. 60 Forthcoming.

Wörsdörfer, M. (2019), “Climate finance - a business-ethical analysis”, Working Paper.

Wulandari, F., Schaefer, D., Stephan, A. and Sun, C. (2018), "Liquidity risk and yield spreads of green bonds", Working Paper.

Zerbib, O.D. (2019), "The effect of pro-environmental preferences on bond prices: evidence from green bonds", Journal of Banking and Finance, Vol. 98, pp. 39-60.

\section{Further reading}

Bagnoli, M.E. and Watts, S.G. (2019), "On the corporate use of green bonds”, Journal of Economics and Management Strategy, Forthcoming.

Banga, J. (2018), "The green bond market: a potential source of climate finance for developing countries", Journal of Sustainable Finance and Investment, Vol. 9 No. 1, doi: 10.1080/ 20430795.2018.1498617.

Baiardi, D., Morana, C, and Climate Change Awareness: Empirical Evidence for the European Union (2020), "University of Milan Bicocca department of economics, management and statistics Wor Dafermos, Yannis and Nikolaidi, Maria and Galanis, Giorgos, climate change, financial stability and monetary policy (2018)", Ecological Economics, Vol. 152, pp. 219-234.

Chang, Y. (2019), "Green finance in Singapore: barriers and solutions (January 17, 2019)”, ADBI Working Paper 915.

Chugan, P.K., Mungra, Y. and Mehta, K. (2017), “Challenges and policy implications for marketing green bonds", Joshi, T., Aagja, J.P. and Parashar, S., (Eds.), Book Titled "Consumer Behaviour and Contemporary Marketing Strategy, Excel India Publishers, New Delhi for IMNU, Jan. 2017, ISBN: $978-93-86256-32-4$, pp. 371-384.

Flammer, C. (2019), "Green bonds: effectiveness and implications for public policy", NBER Working Paper No. w25950.

Ho, H. (2018), "Virginia E., sustainable finance and china's green credit reforms: a test case for bank monitoring of environmental risk", Cornell International Law Journal, Vol. 51 No. 3.

Harrison, C., Partridge, C. and Tripathy, A. (2020), "What's in a greenium: an analysis of pricing methodologies and discourse in the green bond market", The Journal of Environmental Investing, Vol. 10 No. 1.

Hyun, S., Park, D. and Tian, S. (2020), "The price of going green: the role of greenness in green bond markets", Accounting and Finance, Vol. 60 No. 1, pp. 73-95. 
Kila, K. (2018), "Green bonds and the role of the financial sector in tackling global climate change", Working Paper.

Nachemson-Ekwall, S. (2019), “A Swedish market for sustainability-related and socially labelled bonds. Institutional investors as drivers", SSE Working Paper Series in Business Administration No 2019:3, Stockholm School of Economics.

Ndedi, A.A., Kingsly, M. and Luc, M. (2016), "Green bonds as a sustainable way of financing green projects in Cameroon”, Working Paper.

Oche, A. Jr, (2019), "Comparative analysis of the legal regime for green bonds in Nigeria, Philippines and China", Working Paper.

Orlov, S., Rovenskaya, E., Puaschunder, J.M. and Semmler, W. (2017), "Green bonds, transition to a lowcarbon economy, and intergenerational fairness: evidence from an extended DICE model", Working Paper.

\section{Corresponding author}

Jaewon Choi can be contacted at: jaewchoi@illinois.edu 


\begin{tabular}{|c|c|c|c|c|}
\hline Type & $\begin{array}{l}\text { Proceeds raised by bond } \\
\text { sale are }\end{array}$ & Debt recourse & Example & \\
\hline $\begin{array}{l}\text { "Use of proceeds" } \\
\text { bond }\end{array}$ & $\begin{array}{l}\text { Earmarked for green } \\
\text { projects }\end{array}$ & $\begin{array}{l}\text { Recourse to the issuer: same } \\
\text { credit rating of issuer's other } \\
\text { bonds applies }\end{array}$ & $\begin{array}{l}\text { EIB "Climate Awareness } \\
\text { Bond" (backed by EIB); } \\
\text { Barclays Green Bond }\end{array}$ & 189 \\
\hline $\begin{array}{l}\text { "Use of proceeds" } \\
\text { revenue bond or } \\
\text { ABS }\end{array}$ & $\begin{array}{l}\text { Earmarked for or } \\
\text { refinances green projects }\end{array}$ & $\begin{array}{l}\text { Revenue streams from the } \\
\text { issuers through fees, taxes, etc. } \\
\text { are collateral for the debt }\end{array}$ & $\begin{array}{l}\text { State of Hawaii (backed } \\
\text { by fees on state utilities' } \\
\text { electricity bills) }\end{array}$ & \\
\hline Project bond & $\begin{array}{l}\text { Ring-fenced for specific } \\
\text { underlying green project } \\
\text { (s) }\end{array}$ & $\begin{array}{l}\text { Recourse is only to a project's } \\
\text { assets and balance sheet }\end{array}$ & $\begin{array}{l}\text { Invenergy Wind Farm } \\
\text { (backed by Invenergy } \\
\text { Campo Palomas wind } \\
\text { farm) }\end{array}$ & \\
\hline $\begin{array}{l}\text { Securitization } \\
\text { (ABS) bond }\end{array}$ & $\begin{array}{l}\text { Refinance portfolios of } \\
\text { green projects or } \\
\text { proceeds are earmarked } \\
\text { for green projects }\end{array}$ & $\begin{array}{l}\text { Recourse is to a group of } \\
\text { projects that have been grouped } \\
\text { together (e.g. solar leases or } \\
\text { green mortgages) }\end{array}$ & $\begin{array}{l}\text { Tesla Energy (backed by } \\
\text { residential solar leases); } \\
\text { Obvion (backed by green } \\
\text { mortgages) }\end{array}$ & \\
\hline Covered bond & $\begin{array}{l}\text { Earmarked for eligible } \\
\text { projects included in the } \\
\text { covered pool }\end{array}$ & $\begin{array}{l}\text { Recourse to the issuer and, if the } \\
\text { issuer is unable to repay the } \\
\text { bond, to the covered pool }\end{array}$ & $\begin{array}{l}\text { Berlin Hyp green } \\
\text { Pfandbrief; Sparebank } 1 \\
\text { Bolligkredit green covered } \\
\text { bond }\end{array}$ & \\
\hline Loan & $\begin{array}{l}\text { Earmarked for eligible } \\
\text { projects or secured on } \\
\text { eligible assets }\end{array}$ & $\begin{array}{l}\text { Full recourse to the borrower(s) } \\
\text { in the case of unsecured loans. } \\
\text { Recourse to collateral in the case } \\
\text { of secured loans, but may also } \\
\text { feature limited recourse to } \\
\text { borrower(s) }\end{array}$ & $\begin{array}{l}\text { MEP Werke, Ivanhoe } \\
\text { Cambridge and Natixis } \\
\text { Assurances (DUO), OVG }\end{array}$ & \\
\hline $\begin{array}{l}\text { Other debt } \\
\text { instruments }\end{array}$ & $\begin{array}{l}\text { Earmarked for eligible } \\
\text { projects }\end{array}$ & & $\begin{array}{l}\text { Convertible Bonds or } \\
\text { Notes, Schuldschein, } \\
\text { Commercial Paper, Sukuk, } \\
\text { Debentures }\end{array}$ & \\
\hline \multicolumn{4}{|c|}{$\begin{array}{l}\text { Note: }{ }^{a} \text { www.climatebonds.net/market/explaining-green-bonds. This table lists examples of green bond } \\
\text { issuance by supranational organizations, governments and corporations. The table also explains bond } \\
\text { types, the use of proceeds and debt recourse associated with the issuances. }\end{array}$} & $\begin{array}{r}\text { Table A1. } \\
\text { Types of green } \\
\text { bonds }\end{array}$ \\
\hline
\end{tabular}

For instructions on how to order reprints of this article, please visit our website: 